\title{
Anticancer activity of an extract from needles and twigs of Taxus cuspidata and its synergistic effect as a cocktail with 5 -fluorouracil
}

\author{
Weihu Shang ${ }^{1}$, Jinping Qiao', Chenxin Gu', Wei Yin', Jinglei Du', Wei Wang ${ }^{1}$, Meilin Zhu', Mei Han ${ }^{1 *}$ and \\ Weidong $\mathrm{Lu}^{2^{*}}$
}

\begin{abstract}
Background: Botanical medicines are increasingly combined with chemotherapeutics as anticancer drug cocktails. This study aimed to assess the chemotherapeutic potential of an extract of Taxus cuspidata (TC) needles and twigs produced by artificial cuttage and its co-effects as a cocktail with 5-fluorouracil (5-FU).

Methods: Components of TC extract were identified by HPLC fingerprinting. Cytotoxicity analysis was performed by MTT assay or ATP assay. Apoptosis studies were analyzed by H \& E, PI, TUNEL staining, as well as Annexin V/PI assay. Cell cycle analysis was performed by flow cytometry. 5-FU concentrations in rat plasma were determined by HPLC and the pharmacokinetic parameters were estimated using 3p87 software. Synergistic efficacy was subjected to median effect analysis with the mutually nonexclusive model using Calcusyn1 software. The significance of differences between values was estimated by using a one-way ANOVA.

Results: TC extract reached inhibition rates of 70-90\% in different human cancer cell lines (HL-60, BGC-823, KB, Bel7402, and HeLa) but only 5-7\% in normal mouse T/B lymphocytes, demonstrating the broad-spectrum anticancer activity and low toxicity to normal cells of TC extract in vitro. TC extract inhibited cancer cell growth by inducing apoptosis and $\mathrm{G}_{2} / \mathrm{M}$ cell cycle arrest. Most interestingly, TC extract and 5-FU, combined as a cocktail, synergistically inhibited the growth of cancer cells in vitro, with Combination Index values (Cl) ranging from 0.90 to 0.26 at different effect levels from IC50 to IC90 in MCF-7 cells, Cl ranging from 0.93 to 0.13 for IC40 to IC90 in PC-3M-1E8 cells, and $\mathrm{Cl}<1$ in A549 cells. In addition, the cocktail had lower cytotoxicity in normal human cell (HEL) than 5-FU used alone. Furthermore, TC extract did not affect the pharmacokinetics of 5-FU in rats.

Conclusions: The combinational use of the TC extract with 5-FU displays strong cytotoxic synergy in cancer cells and low cytotoxicity in normal cells. These findings suggest that this cocktail may have a potential role in cancer treatment.
\end{abstract}

\section{Background}

Cancer is a multifactorial disease that requires a multitargeted therapeutic approach $[1,2]$. Chemotherapy has undergone a gradual transition from mono-substance therapy toward multidrug therapy, and drug cocktails strategy has become widely adopted. Properly formulated drug combinations are believed to enhance

\footnotetext{
* Correspondence: hanmei@bnu.edu.cn; weidong_lu@dfci.harvard.edu 'Key Laboratory of Radiopharmaceuticals, Ministry of Education, College of Chemistry, Beijing Normal University, Beijing 100875, China

2Leonard P. Zakim Center, Dana-Farber Cancer Institute, Harvard Medical School, Boston, MA 02115, USA

Full list of author information is available at the end of the article
}

synergy, and interactions of chemical components within the combination may improve therapeutic efficacy over single drugs [3-6]. Botanical medicines are generally plentiful, low cost, and relatively non-toxic in clinical practice, and in many cases plant extracts are thought to be therapeutically superior to their single isolated constituents $[7,8]$. Therefore, botanical medicines are increasingly combined with chemical medicines in anticancer drug cocktails, especially in countries where botanical medicines are well-accepted $[9,10]$. Some studies have suggested that for cancer treatment, drug cocktails combining botanical and chemical medicines 
may exhibit enhanced efficacies with diminished side effects and complications [11-13].

Taxus cuspidata (TC), also called Japanese yew, is an evergreen tree with anticancer and anti-inflammatory activities [14-16]. While $T C$ is scarce as a natural resource, artificial cuttage is reproducible and makes $T C$ needles and twigs constantly available. $\mathrm{DaKeSu}$, a TC extract of $T C$ needles and twigs produced by artificial cuttage, has been under preclinical and clinical investigation in China as a botanical medicinal product $[17,18]$. Chinese language sources have reported animalbased and preclinical studies showing DaKeSu activity against breast, lung, and digestive tract cancers $[17,18]$, but the anticancer spectrum and mechanism of the extract have not been studied in detail.

5-Fluorouracil (5-FU) is one of the most commonly used drugs for treatment of breast, digestive tract, and other cancers [19-21]. It is often used clinically in combination with other agents such as paclitaxel, docetaxel, and cisplatin [22-24]. A few studies have shown synergistic effects of combinations of 5-FU with botanical medicines or components thereof. For example, oroxylin A, a bioactive Scutellaria baicalensis Georgi flavonoid, has synergistic effect with 5-FU on HepG2 human hepatocellular carcinoma and on $\mathrm{H}_{22}$ transplanted mice [25]. Chan-Yu-Bao-Yuan-Tang, an herbal medicine formula, induced apoptosis synergistically with 5 -FU in lung and cervical cancer cells [26]. Though botanical medicines and 5-FU are both commonly used in clinical practice, there have been far fewer studies combining 5-FU and botanical medicines than on 5-FU or botanical medicines alone.

The aim of this paper is to evaluate the efficacy of the extract of $T C$ needles and twigs produced by artificial cuttage as a source of useful anticancer agents and the co-efficacy at the cellular level of a cocktail combining $T C$ extract and 5-FU. We also assessed whether TC extract would influence the pharmacokinetics of 5-FU in animals. These results show the utility for identifying herb-chemotherapeutic drug combinations.

\section{Methods}

\section{Reagents, cell lines, and animals}

5-FU (99.9\% purity) was purchased from Shanghai Bangcheng Chemical Co., Ltd. (Shanghai, China). The TC extract was kindly provided by China Hongdoushan Tech. Co., Ltd. (Heilongjiang, China). HPLC-grade methanol and acetonitrile were purchased from Fisher Scientfic (Fair Lawn, NJ, USA).

The human cancer cell lines, MCF-7 (breast), PG and A549 (lung), PC-3M-1E8 (prostate), BGC-823 (gastric), WM451 (melanoma), Bel-7402 (hepatocellular), KB (oral squamous), HeLa (cervical), and HL-60 (leukemic), and the normal cells, mouse spleen $\mathrm{T}$ lymphocytes ( $\mathrm{T}$ cells), mouse spleen B lymphocytes (B cells), and a human embryonic lung cell line (HEL), were kindly provided by the Department of Pathology, Peking University Health Science Center. The cells were maintained in RPMI1640 medium supplemented with $10 \%$ fetal bovine serum (Gibco, Carlsbad, CA), $100 \mathrm{IU} / \mathrm{ml}$ penicillin and $100 \mathrm{IU} / \mathrm{ml}$ streptomycin in $5 \% \mathrm{CO}_{2}$ humidified atmosphere at $37^{\circ} \mathrm{C}$.

Ten male Sprague-Dawley rats (6-7 weeks old, 200$250 \mathrm{~g}$ ) were purchased from Vital River (Beijing, China). Five rats in the control group received physiological saline orally ( $20 \mathrm{ml} / \mathrm{kg}$ b.i.d. for 8 days), and the other 5 rats in the $T C$ extract-pretreated group received a suspension of $T C$ extract orally $(0.25 \mathrm{~g} / \mathrm{kg}$ b.i.d. for 8 days). After the 8-day treatment period, both groups of rats received 5 -FU ( $48 \mathrm{mg} / \mathrm{kg}$ ) by intraperitoneal (i.p.) injection after a 12-h fast. All animals were maintained according to the international guidelines for care and use of laboratory animals and all experimental procedures involving animals were approved by the Ethics Committee of Beijing Normal University (BNU/EC/01/ 2011).

\section{Extract identification}

For HPLC fingerprinting, TC extract was dissolved in methanol and filtered through membrane filters $(0.45$ $\mu \mathrm{m}$ pore size). A Waters HPLC system equipped with a 1525 pump and a 2487 UV detector (Waters, USA) was used. A C18 column $(4.6 \mathrm{~mm} \times 250 \mathrm{~mm}, 5 \mu \mathrm{m}$, Kromasil) was used as the solid phase, the mobile phase consisted of $\mathrm{CH}_{3} \mathrm{CN}$-water (50:50, v/v) (A) and $\mathrm{CH}_{3} \mathrm{CN}$ water $(15: 85, \mathrm{v} / \mathrm{v})(\mathrm{B})$, and the elution gradient profile was as follows: $0-15 \mathrm{~min}, 0 \% \mathrm{~A} ; 15-20 \mathrm{~min}, 10 \% \mathrm{~A} ; 20-$ $40 \mathrm{~min}, 25 \% \mathrm{~A} ; 40-60 \mathrm{~min}, 40 \% \mathrm{~A} ; 60-80 \mathrm{~min}, 50 \% \mathrm{~A}$; $80 \mathrm{~min}, 100 \% \mathrm{~A}$. The flow rate was $0.8 \mathrm{ml} / \mathrm{min}$, the column temperature was room temperature, the injection volume was kept at $10 \mu \mathrm{l}$; the scan wavelength was set from 190 to $370 \mathrm{~nm}$, and the detection wavelength was set at $227 \mathrm{~nm}$.

\section{Cell viability assay}

The cell viability was evaluated for both cancer and normal cell lines by MTT assay on 96-well plates [27] or ATP assay on 384-well plates as previously described [28]. For the MTT assay, cells were seeded on 96-well plates at $4 \times 10^{4}$ cells $/ \mathrm{ml}$ over night. Then cells were treated with $10 \mu \mathrm{g} / \mathrm{ml} \mathrm{TC}$ extract for $72 \mathrm{~h} .10 \mu \mathrm{l}$ of a 5 $\mathrm{mg} / \mathrm{ml}$ MTT solution was added to each well and the plate was incubated at $37^{\circ} \mathrm{C}$ for $4 \mathrm{~h}$. Subsequently, 100 $\mu \mathrm{l} 0.1 \% \mathrm{NH}_{4} \mathrm{Cl}$ and $10 \%$ dodecyl phenyl sodium sulfonate solution was added to each well, and the plates were incubated overnight at $37^{\circ} \mathrm{C}$. Absorbance was detected using a Victor ${ }^{3} \mathrm{~V}$ Multilabel reader (PerkinElmer, USA) with the filter set to $570 \mathrm{~nm}$ (reference 
wavelength $650 \mathrm{~nm}$ ). The ATP assay used the CellTiterGlo ${ }^{\circledR}$ Luminescent Cell Viability Assay kit (Madison, WI, USA). Briefly, cells were seeded on 384-well plates at $2 \times 10^{4}$ cells $/ \mathrm{ml}$ over night. Various concentrations of single 5-FU, single $T C$ extract or combination (1:1) in the same volume $(0.1,0.3,1,3,10,30,100,300 \mu \mathrm{g} / \mathrm{ml})$ were added and the plates were incubated at $37^{\circ} \mathrm{C}$ for $72 \mathrm{~h}$. The detection protocol included the addition of 10 $\mu \mathrm{l}$ of the working solution of the ATP kit to each well. The luminescence of each well was measured using a Victor $^{3} \mathrm{~V}$ Multilabel reader (PerkinElmer, USA).

\section{Histology and immunohistochemistry}

Cells were cultured in chamber slides on 6-well plates at $5 \times 10^{5}$ cells $/ \mathrm{ml}$ and allowed to attach overnight, followed by treatment with $10 \mu \mathrm{g} / \mathrm{ml} \mathrm{TC}$ extract for $24 \mathrm{~h}$. Cells were washed with phosphate-buffered saline (PBS), fixed with freshly prepared ice-cold $4 \%$ paraformaldehyde, and then stained with $\mathrm{H}$ \& E (St. Louis, MO, USA). Cells were observed using a Leica DM-RXA microscope.

Cells were treated with $T C$ extract for $24 \mathrm{~h}$, harvested by trypsinization, washed twice with PBS, and fixed for $1 \mathrm{~h}$ in $1 \%$ paraformaldehyde. After RNase treatment, the cells were adjusted to a density of $1 \times 10^{6}$ cells $/ \mathrm{ml}$, and then stained with PI (St. Louis, MO, USA). Immunofluorescent images were acquired using a Leica TCSNT confocal microscopy.

TUNEL staining was performed using an Apo-Direct kit (San Diego, USA) according to the manufacturer's instructions. Briefly, cells were cultured in chamber slides on 6 -well plates at $5 \times 10^{5}$ cells $/ \mathrm{ml}$ over night. Then cells were treated with $10 \mu \mathrm{g} / \mathrm{ml}$ TC extract for 24 h. The cells were fixed with $4 \%$ paraformaldehyde for 60 min at room temperature, washed 3 times with PBS, permeabilized with $0.1 \%$ Triton $\mathrm{X}-100$ in $0.1 \%$ sodium citrate, and then rinsed with PBS. Cells were stained with $50 \mu \mathrm{l}$ TUNEL reaction mixtures at $37^{\circ} \mathrm{C}$ for $60 \mathrm{~min}$ and washed with PBS. Afterwards, the cells were viewed using an optical microscope.

\section{Annexin V/PI Assay}

Annexin V/PI assay was determined using the AnnexinV FITC Staining kit (Beijing Biosea Biotechnology Co., LTD, China) in combination with propidium iodide, according to the manufacturer's instructions. Briefly, cells were cultured in T25 flasks at a density of $5 \times 10^{5}$ cells $/ \mathrm{ml}$ and allowed to attach overnight, followed by treatment with $10 \mu \mathrm{g} / \mathrm{ml} \mathrm{TC}$ extract for $48 \mathrm{~h}$. Cells were washed with PBS and incubated with Annexin-V FITC labeling solution (containing $10 \mu \mathrm{l}$ Annexin-V- FITC labeling reagent in $300 \mu$ incubation buffer) for $15 \mathrm{~min}$ at room temperature and then added $5 \mu \mathrm{l}$ propidium iodide solution. Analysis was carried out by flow cytometry (FACS Calibur, Becton-Dickinson, USA) and confocal microscopy (Leica, Germany).

\section{Flow cytometry analysis}

Cells were cultured in T25 flasks at a density of $5 \times 10^{6}$ cells $/ \mathrm{ml}$ and treated with a series of different concentrations of $T C$ extract $(0,1.67,4.16,8.33,33.33$, and 66.67 $\mu \mathrm{g} / \mathrm{ml}$ ) for $24 \mathrm{~h}$. The cells were harvested by trypsinization and washed twice with PBS. For cell cycle and apoptosis assays, cells were fixed gently in cold $70 \%$ ethanol at $4^{\circ} \mathrm{C}$ overnight and then re-suspended in PBS with $0.1 \mathrm{mg} / \mathrm{ml}$ RNAse A and $0.1 \%$ Triton X-100 and incubated at $37^{\circ} \mathrm{C}$ for $30 \mathrm{~min}$. The cell cycle phase and presence of apoptotic nuclei were determined by staining with PI. Flow cytometry analyses were performed using a FACSCalibur instrument and CellQuest software (Becton Dickinson, USA).

\section{Pharmacokinetic study}

Blood samples $(0.5 \mathrm{ml})$ were collected from the retroorbital plexus of rats under light ether anaesthesia into heparinized tubes at $0,1,3,5,10,20,30,60,90,120$, and $240 \mathrm{~min}$ after dosing with 5 -FU. Blood samples were centrifuged at $7000 \mathrm{rpm}$ for $5 \mathrm{~min}$. Drug-containing plasma $(200 \mu \mathrm{l}), 200 \mu \mathrm{l}(1 \mathrm{mg} / \mathrm{ml})$ internal standard (IS) solution, and $600 \mu \mathrm{l}$ methanol were added to a $2-\mathrm{ml}$ centrifuge tube for the assay. The sample was shaken for 1 min using a vortex mixer and then extracted with ethyl acetate/isopropanol (9:1, v/v). The mixture was then centrifuged at $3000 \mathrm{rpm}$ for $5 \mathrm{~min}$, and the upper layer was pipetted into a clean 5 - $\mathrm{ml}$ centrifuge glass tube. The sample was then extracted twice more in the same way. The supernatant was mixed and evaporated to dryness under nitrogen at $40^{\circ} \mathrm{C}$. The dried residues were reconstituted in $200 \mu \mathrm{l}$ of methyl cyanide/methanol $(75: 25, \mathrm{v} / \mathrm{v})$, vortex-mixed for $10 \mathrm{~s}$, and centrifuged at $3000 \mathrm{rpm}$ for $5 \mathrm{~min}$, and the supernatant was analyzed by HPLC.

The plasma concentrations of 5-FU were determined by HPLC. The HPLC system comprised a 1525 pump and 2487 UV detector (Waters, USA). An Atlantis DC C18 column $(3 \mu \mathrm{m}, 30 \mathrm{~mm} \times 2.1 \mathrm{~mm}$, Waters, USA) was used. The mobile phase consisted of $10 \mathrm{mM}$ ammonium acetate in water (A) and acetonitrile (B). The gradient program was linearly increased from $10 \%$ B to $80 \% \mathrm{~B}$ in the first $2 \mathrm{~min}$, held for $2 \mathrm{~min}$, and then returned to $10 \% \mathrm{~B}$. The flow rate was $0.2 \mathrm{ml} / \mathrm{min}$. The end time of the program was set at $6 \mathrm{~min}$. and the detection wavelength was $254 \mathrm{~nm}$ [29].

\section{Combination index $(\mathrm{Cl})$ for determining synergism additivity or antagonism}

The combined effects of TC extract and 5-FU were subjected to median effect analysis with the mutually 
nonexclusive model as previously described [30]. The combination index (CI) for determining synergism and antagonism between the substances was calculated using Calcusyn1 software (ver 1.1.1, 1996; Biosoft Inc., Cambridge, $\mathrm{UK})$. $\mathrm{CI}<1, \mathrm{CI}=1$, and $\mathrm{CI}>1$ indicated synergism, additivity, and antagonism, respectively. The results by ATP assay were analyzed for CI determination.

\section{Statistical analysis}

The significance of differences between values was estimated by using a one-way ANOVA. $\mathrm{P}<0.05$ was considered statistically significant.

\section{Results}

\section{Component identification of TC extract by HPLC} fingerprinting

Chromatographic fingerprinting is a powerful technology for authentication of natural products. The application of chromatographic fingerprinting in component identification of natural products continues to expand. HPLC fingerprinting of TC extract for quality control is shown in Figure 1A. The 8 main



B

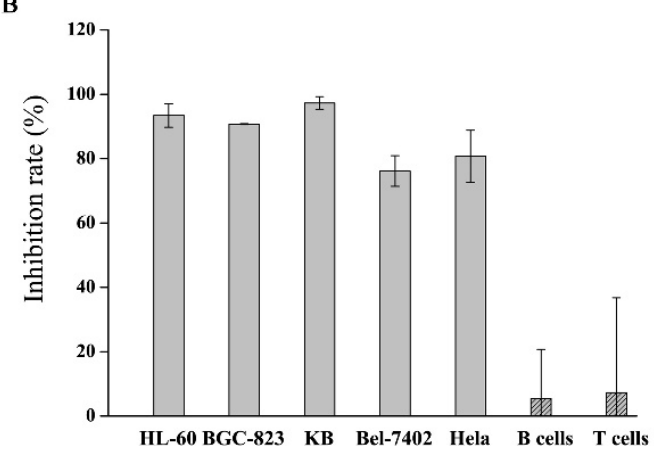

Figure 1 Chemical composition and cytotoxic activity of TC extract. (A) Peaks: 1, taxine A (5.00\%); 2, 10-DAB III (1.45\%); 3, 9hydroxyl-13-acetylbaccatin III (9.38\%); 4, 7-xyl-10-DAT (9.63\%); 5 , baccatin III (8.32\%); 6, 10-DAT (6.31\%); 7, cephalomannine $(2.67 \%) ; 8$, paclitaxel (2.25\%). (B) Differences in TC extract cytotoxicity in 5 human cancer cell lines and normal mouse spleen $B$ and $T$ lymphocytes. The cell growth inhibition was quantified by the MTT assay. Cells were treated with $10 \mu \mathrm{g} / \mathrm{ml}$ TC extract for $72 \mathrm{~h}$. The data shown are from 3 independent experiments. compounds of $T C$ extract found in this study are in agreement with previous reports [9,31-33]. The taxoids contained high proportions of 7-xyl-10-DAT (9.63\%), 9-hydroxyl-13-acetylbaccatin III (9.38\%), and baccatin III $(8.32 \%)$, moderate amounts of 10 -DAT $(6.31 \%)$ and taxine A (5.00\%), and low amounts of cephalomannine (2.67\%), paclitaxel (2.25\%), and 10-DAB III (1.45\%). The structures of these compounds are shown in Additional file 1.

\section{TC extract inhibits growth of human cancer cells but not normal cells}

To explore the effects of $T C$ extract on human cancer cell lines and normal cells in vitro, the cytotoxicity of $T C$ extract at $10 \mu \mathrm{g} / \mathrm{ml}$ for $72 \mathrm{~h}$ was assessed by MTT assays in a panel of human cancer cell lines namely HL60, BGC-823, Bel-7402, KB, HeLa and normal mouse T/ $\mathrm{B}$ lymphocytes. Figure $1 \mathrm{~B}$ shows that growth was strongly inhibited in all cancer cells by $93 \%$ for HL-60 cells, $90 \%$ for BGC-823 cells, $97 \%$ for KB cells, $76 \%$ for Bel-7402 cells, and $80 \%$ for HeLa cells. In contrast, growth of mouse spleen T/B lymphocytes was inhibited only $7 \%$ and $5 \%$, respectively. Therefore, TC extract showed strong and broad-spectrum anticancer activity with low toxicity to normal cells.

\section{TC extract induces apoptosis and arrests human cancer cells at the $G_{2} / M$ phase}

We next performed 3 separate apoptosis assays, $\mathrm{H} \& \mathrm{E}$, PI, and TUNEL staining, to determine whether TC extract inhibited cell growth by inducing apoptosis. Treatment with $10 \mu \mathrm{g} / \mathrm{ml}$ of $T C$ extract for $24 \mathrm{~h}$ produced significant morphological changes in PC-3M1 E8 cells compared with control cells. As shown in Figure 2, TC extract-treated cells displayed cellular shrinkage and nucleoli ambiguity by $\mathrm{H}$ \& E staining, nuclear fragmentation by PI staining, and TUNELpositive staining, all typical characteristics of apoptosis, compared with control cells. Similar effects were seen in PG and WM451 cells (data not shown). These results demonstrated that $T C$ extract inhibited cell growth by inducing apoptosis.

To further measure percentage distribution of $T C$ extract-induced apoptotic and necrotic human cancer cells, Annexin V/PI assay was used. Figure 3A shows specific percentage distributions of PC-3M-1E8 cells as obtained by flow cytometry. Moreover, confocal microscopy analysis (Figure 3B) demonstrated that significant apoptosis occured in TC extract-treated PC-3M-1E8 cells as depicted by strong reaction of these cells with the Annexin V antibody (green) compared to control cells. Some propidium iodide staining (red) was also noted in the cells, indicating very late stage apoptosis or necrosis. 


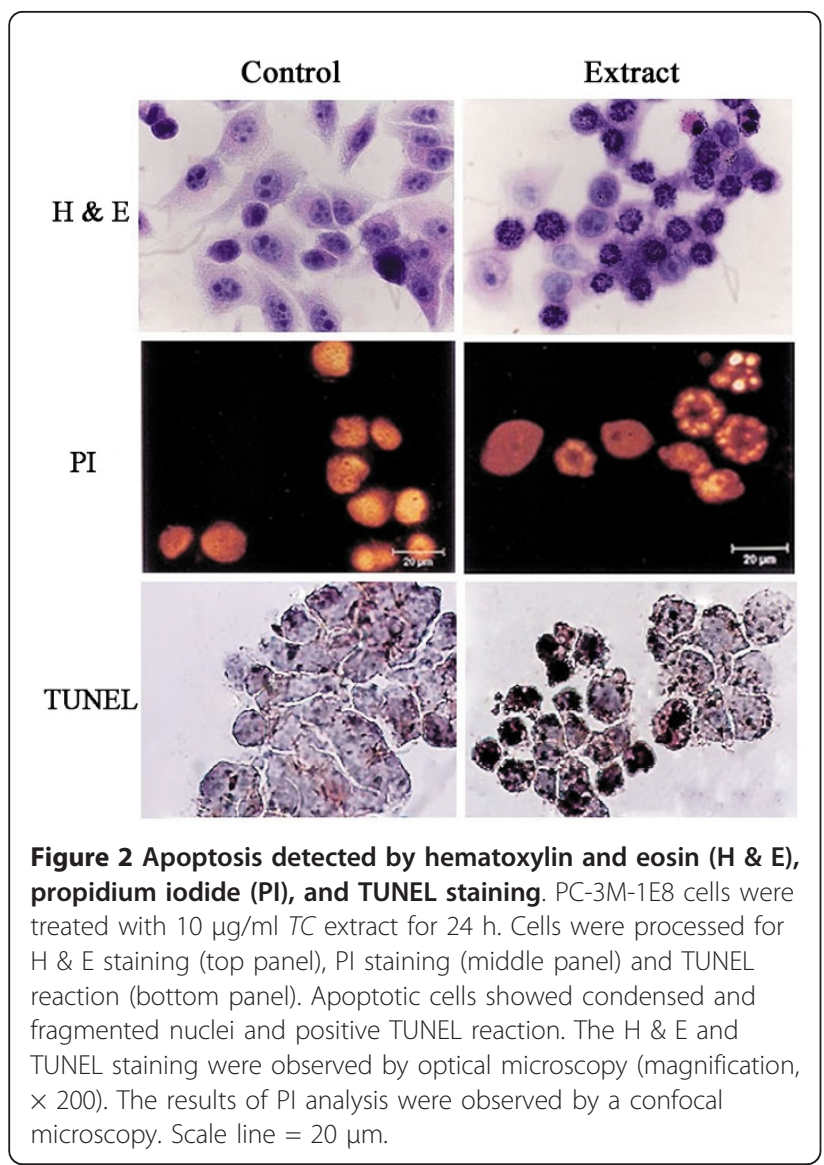

We also performed sub-DNA and cell cycle analysis by flow cytometry in PC-3M-1E8 cells treated with different concentrations of $T C$ extract for $24 \mathrm{~h}$. As shown in Figure 4, the cell population in sub-G1 (APO in Figure 4) gradually increased with $T C$ extract treatment in a dose-dependent manner, indicating increasing degrees of apoptosis triggered by the extract. As shown in Figure 4 and Table 1 , we also observed gradual dose-dependent decreases in the $G_{0} / G_{1}$ phase population (23\%-6\%) as compared with a negative control (36\%) and increases in the $G_{2} / M$ phase population ( $\left.64 \%-84 \%\right)$ as compared with a negative control (50\%) with increasing concentrations of $T C$ extract, indicating that the cell cycle was arrested at the $\mathrm{G}_{2} / \mathrm{M}$ phase. $T C$ extract had similar effects in PG and WM451 cells (data not shown).

Combination of 5-FU and TC extract produced synergistic effects on human cancer cells with lower cytotoxicity in normal cells than 5 -FU alone

In order to investigate the anticancer activity of a cocktail containing $T C$ extract and 5-FU, cytotoxic studies were performed in cancerous (A549, PC-3M-1E8, and MCF-7) and normal (HEL) human cell lines. As shown in Figure 5, the viability levels of all cell lines decreased
A

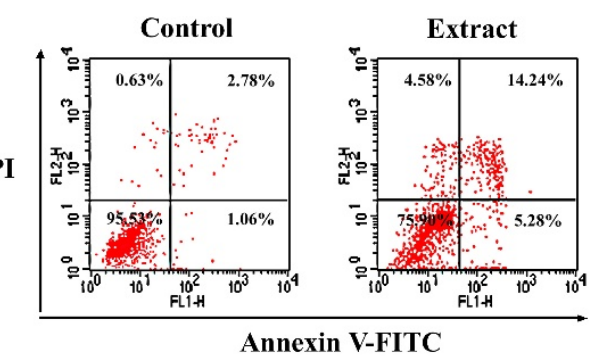

B
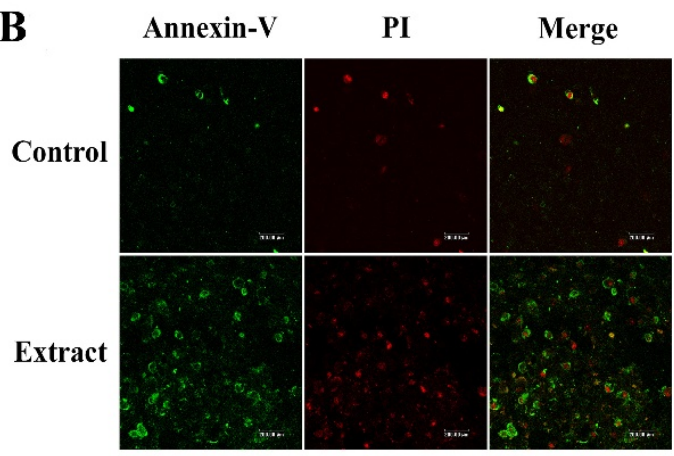

Figure 3 Apoptotic percentage distribution and observation by Annexin V/PI assay. PC-3M-1E8 cells were treated with $10 \mu \mathrm{g} / \mathrm{ml}$ TC extract for $48 \mathrm{~h}$ and stained with annexin V-FITC antibody (green staining) and propidium iodide (red staining) and analysed by flow cytometry (A) and observed using a confocal microscopy (B). Scale line $=200 \mu \mathrm{m}$.

in a dose-dependent manner with increasing doses of different treatments. The survival of PC-3M-1E8 cells decreased from $84 \%$ to $17 \%$ with increasing doses (0.1$300 \mu \mathrm{g} / \mathrm{ml}$ ) of $T C$ extract, from $77 \%$ to $14 \%$ with increasing dose $(0.1-300 \mu \mathrm{g} / \mathrm{ml})$ of the $5-\mathrm{FU}$, and from $67 \%$ to $3 \%$ with the combination. In addition, $T C$ extract concentrations above $10 \mu \mathrm{g} / \mathrm{ml}$ significantly enhanced the inhibitory effects of 5-FU at the same concentrations (Figure 5C). The same tendency was observed in A549 and MCF-7 cells, where the changes in cell survival levels with cocktail treatment were statistically significant compared with 5-FU treatment alone (Figure 5A and $5 \mathrm{~B}$ ). Furthermore, the combination of 5-FU and $T C$ extract showed not only no significant inhibition of HEL cell growth compared with the individual treatments, even at a concentration of $100 \mu \mathrm{g} / \mathrm{ml}$, but also lower cytotoxicity than 5-FU alone (Figure 5D).

To determine whether the combined effects of the extract and 5-FU were synergistic, the $\mathrm{CI}$ value was calculated where $\mathrm{CI}<1,=1$, and $>1$ represent synergism, additive effect, and antagonism, respectively. The CI-fa curve shown in Figure 6 indicates that the 5-FU and the $T C$ extract combination yielded synergistic effects with $\mathrm{CI}$ values ranging from 0.90 to 0.26 at different effect levels from IC50 to IC90 in MCF-7 cells (Figure 6B), 


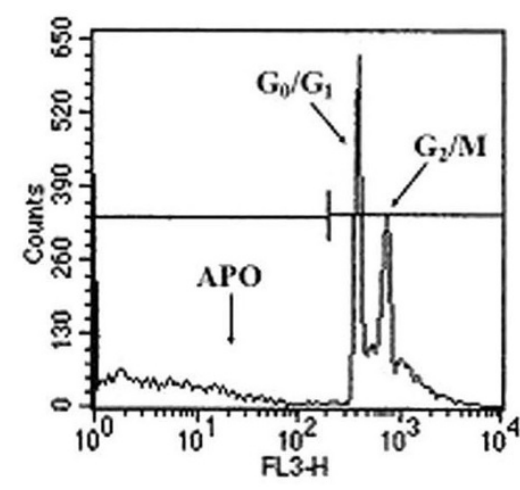

A

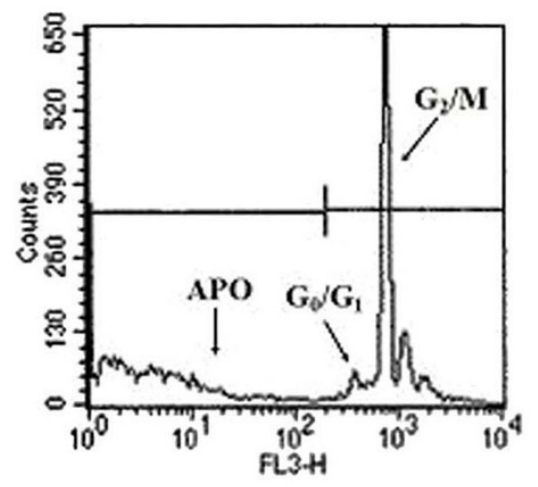

D

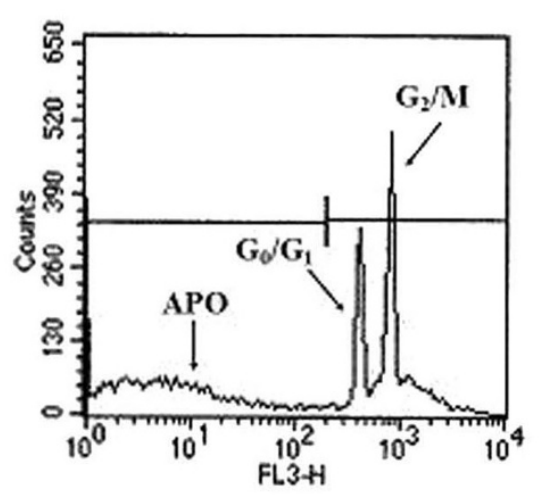

B

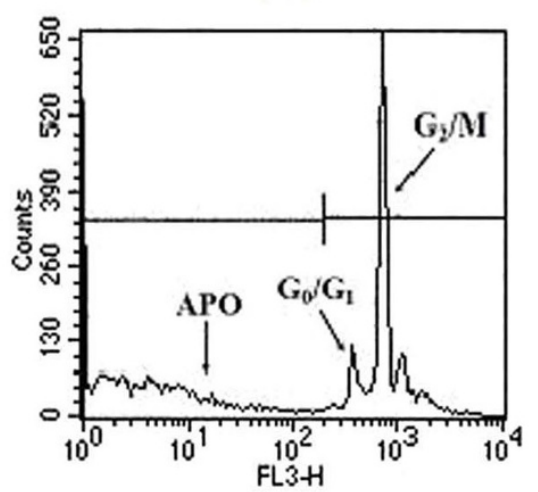

E

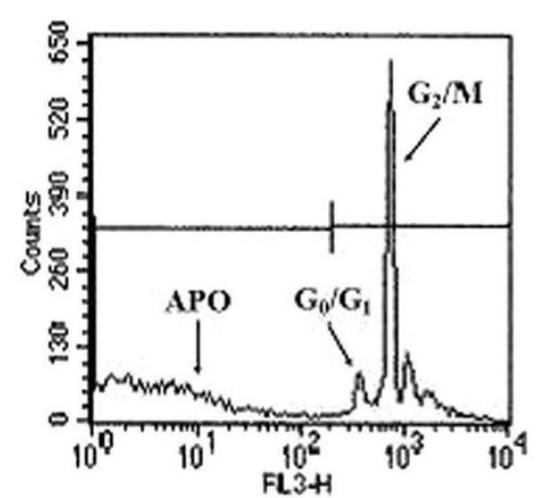

$\mathrm{C}$



$\mathrm{F}$

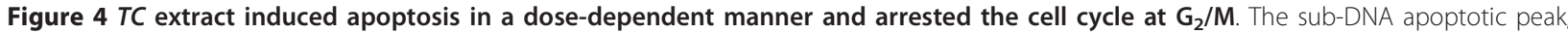
$\mathrm{G}_{0} / \mathrm{G}_{1}$ peak, and $\mathrm{G}_{2} / \mathrm{M}$ peak were quantified by flow cytometry after treatment of PC-3M-1E8 cells for $24 \mathrm{~h}$ with the following concentrations of TC extract: $0 \mu \mathrm{g} / \mathrm{ml}$ as a control (A), $1.67 \mu \mathrm{g} / \mathrm{ml}$ (B), $4.16 \mu \mathrm{g} / \mathrm{ml}$ (C), $8.33 \mu \mathrm{g} / \mathrm{ml}$ (D), $33.33 \mu \mathrm{g} / \mathrm{ml}$ (E), and $66.67 \mu \mathrm{g} / \mathrm{ml}$ (F). The cells were stained with propidium iodide and analysed by flow cytometry.

with CI ranging from 0.93 to 0.13 for IC40 to IC90 in PC-3M-1E8 cells (Figure 6C), and with $\mathrm{CI}<1$ in A549 cells (Figure 6A). In contrast, the CI values were always $>1$ in HEL cells (Figure 6D), indicating that the cytotoxic effect of the combination in normal cells was antagonistic. These results showed that the cytotoxic effect of the combination of $T C$ extract and 5-FU was strongly synergistic in human cancer cells but antagonistic in normal cells.

After treated with 5-FU, TC extract or combination for $72 \mathrm{~h}$, cells images were captured. Each image was divided into nine equal pieces and one of them was chosen at random then the number of cells was counted. As shown in Figure 7, compared with the control, the cell

Table 1 Effect of TC extract on cell cycle distribution in PC-3M-1E8 cells.

\begin{tabular}{cccc}
\hline TC extract concentration & \multicolumn{2}{c}{ Cell cycle (\%) } \\
\cline { 2 - 4 } & $\mathbf{G}_{\mathbf{0}} / \mathbf{G}_{1}$ & $\mathbf{S}$ & $\mathbf{G}_{2} / \mathbf{M}$ \\
\hline $0 \mu \mathrm{g} / \mathrm{ml}$ & $36.58 \pm 1.39$ & $12.49 \pm 2.1$ & $50.93 \pm 0.93$ \\
$1.67 \mu \mathrm{g} / \mathrm{ml}$ & $23.61 \pm 2.01^{*}$ & $9.59 \pm 0.53 *$ & $66.79 \pm 1.48 *$ \\
$4.16 \mu \mathrm{g} / \mathrm{ml}$ & $21.09 \pm 2.64^{*}$ & $10.74 \pm 0.92 *$ & $68.16 \pm 1.86 *$ \\
$8.33 \mu \mathrm{g} / \mathrm{ml}$ & $6.88 \pm 0.74^{*}$ & $9.05 \pm 3.33^{*}$ & $84.07 \pm 3.82^{*}$ \\
$33.33 \mu \mathrm{g} / \mathrm{ml}$ & $6.67 \pm 1.54 *$ & $9.71 \pm 1.89 *$ & $83.62 \pm 3.38^{*}$ \\
$66.67 \mu \mathrm{g} / \mathrm{ml}$ & $9.46 \pm 1.08^{*}$ & $8.94 \pm 1.08 *$ & $81.60 \pm 1.95 *$ \\
\hline
\end{tabular}

Cell cycle distributions in PC-3M-1E8 cells exposed to TC extract for $24 \mathrm{~h}$, as determined by flow cytometry using propidium iodide staining. Values are mean \pm SEM of 3 experiments. *Significantly different from $0 \mu \mathrm{g} / \mathrm{ml}(P<0.05)$. 

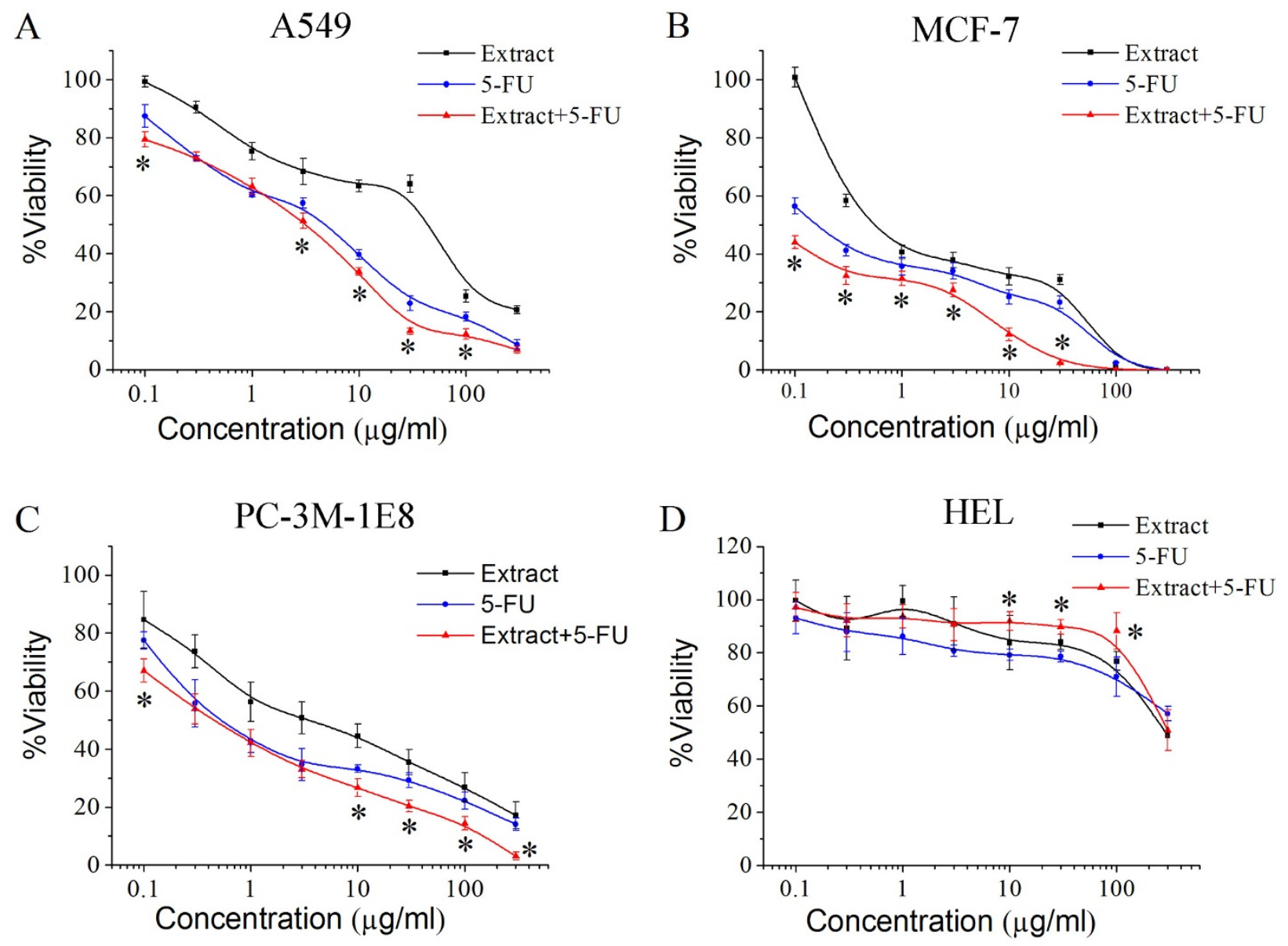

Figure 5 Effect of TC extract and 5-FU on growth of human cancer cell lines and normal cells. Human lung cancer cell line A549 (A), human breast cancer cell line MCF-7 (B), human prostate cancer cell line PC-3M-1E8 (C), and human embryo lung cell line HEL (D) were exposed to graded concentrations of TC extract $(0.1-300 \mu \mathrm{g} / \mathrm{ml}), 5-\mathrm{FU}(0.1-300 \mu \mathrm{g} / \mathrm{ml})$, or the combination for $72 \mathrm{~h}$. The proportion of live cells was quantified by ATP assay. Each point represents the mean \pm S.D. $(n=5)$, and asterisks indicate significance at $P<0.05$, compared with 5 -FU alone.

numbers of the 3 human cancer cell lines decreased remarkably after treatment with either $T C$ extract or 5FU individually and even further after treatment with the combination. Nevertheless, the numbers of normal cells (HEL) were nearly the same, and the cells appeared healthy. The observations provided additional support to earlier results that the effect on inhibition of cell growth of combining $T C$ extract and 5-FU was synergistic in human cancer cells and antagonistic in normal cells.

\section{TC extract does not affect the pharmacokinetics of 5-FU} in rats

The plasma concentration-time curves for the two groups after a single i.p. injection of 5-FU were adequately described by a first-order absorption two-compartment open model (Figure 8). The pharmacokinetic parameters were estimated using 3p87 software (Chinese
Pharmacological Society, Beijing, China) and summarized in Table 2. None of the pharmacokinetics parameters, including the area under the curve (AUC), the time to reach the maximum concentration $\left(\mathrm{T}_{\max }\right)$, the maximum concentration $\left(\mathrm{C}_{\max }\right)$, or the absorption halflife $\left(\mathrm{T}_{1 / 2}\right)$, showed any significant difference between the $T C$ extract-pretreated group and the control group. These results indicates that $T C$ extract did not affect the pharmacokinetics of 5-FU.

\section{Discussion}

In this study, we evaluated the anticancer activity of $T C$ extract from the needles and twigs of $T C$, alone and in combination with 5 -FU, in vitro. The pharmacokinetic interactions were further explored in rats. This study found that $T C$ extract had a strong cytotoxicity to the 10 common human cancer cell lines (BGC-823, PG, 

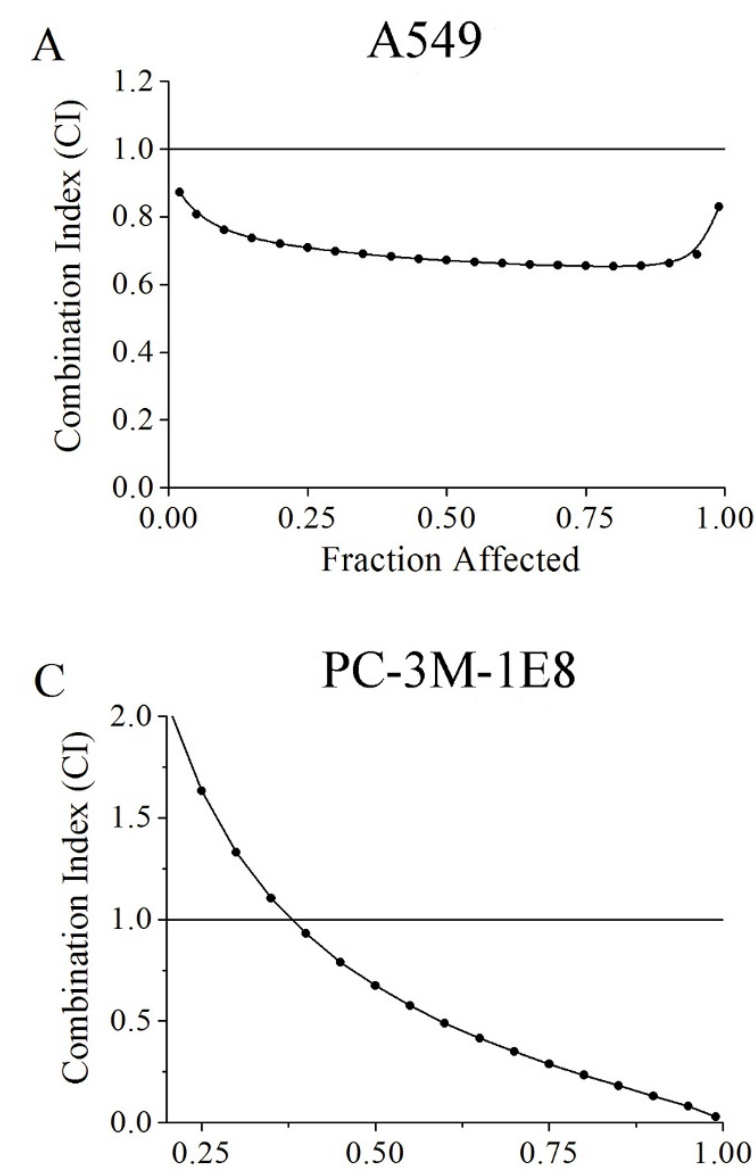


Figure 6 Synergistic antitumor effect of the combination of TC extract and 5-FU in vitro. Combination index (Cl) of TC extract with 5-FU in human lung cancer cell line A549 (A), human breast cancer cell line MCF-7 (B), human prostate cancer cell line PC-3M-1E8 (C), and human embryo lung cell line HEL (D) was calculated as described. Here, Fraction Affected on the x-axis denotes the proportion of cells affected (e.g., a

Fraction Affected of 0.5 is equivalent to a $50 \%$ reduction in cell growth).

WM451, Bel-7402, KB, HeLa, HL-60, MCF-7, A549, and PC-3M-1E8), which shown that it had broad-spectrum anticancer activity in vitro. Besides, it exhibited low toxicity to normal cells (mouse splenic T/B lymphocytes and HEL cells). TC extract inhibited cancer cell growth by inducing apoptosis and $\mathrm{G}_{2} / \mathrm{M}$ arrest. Moreover, the combination of $T C$ extract with 5 -FU showed higher inhibition in a number of human cancer cell lines (A549, MCF-7, and PC-3M-1E8) and lower cytotoxicity in normal cells (HEL). In addition, the pharmacokinetics of 5-FU were not affected by combination with $T C$ extract. In summary, the effect of combining $T C$ extract with 5 -FU on cell growth inhibition was synergistic in cancer cells and antagonistic in normal cells. This cocktail may therefore have great pharmaceutical potential.

$T C$ is one of the most extensively studied yew species, and more than 150 taxanes and other compounds have been reported [34]. Paclitaxel, one component of TC, is a popular anticancer drug used in clinical practice to treat ovarian, breast, and other carcinomas [23,31]. As an antimitotic agent, it induces cell apoptosis and $G_{2} / M$ arrest. In our study, HPLC fingerprinting identified 7 main taxoids in addition to paclitaxel in the extract. It has been reported that some of the taxoids found in the extract, such as baccatin III, 10-DAB, and cephalomannine, also interact with microtubules and inhibit the microtubule depolymerization process $[14,23]$. These could also inhibit human cancer cell growth as antimitotic agents. Therefore, the taxoids in TC extract may combine to kill human cancer cells by apoptosis and $\mathrm{G}_{2} / \mathrm{M}$ arrest.

Kano et al. [35] found that different sequences of paclitaxel and 5-FU administration had different efficacies and toxicities. For example, treatment with paclitaxel preceding 5-FU produced additive or synergistic cytotoxicity in vitro, while simultaneous exposure to paclitaxel and 5-FU showed mainly subadditive effects in A549, MCF-7, and WiDr cell lines. This is in contrast 


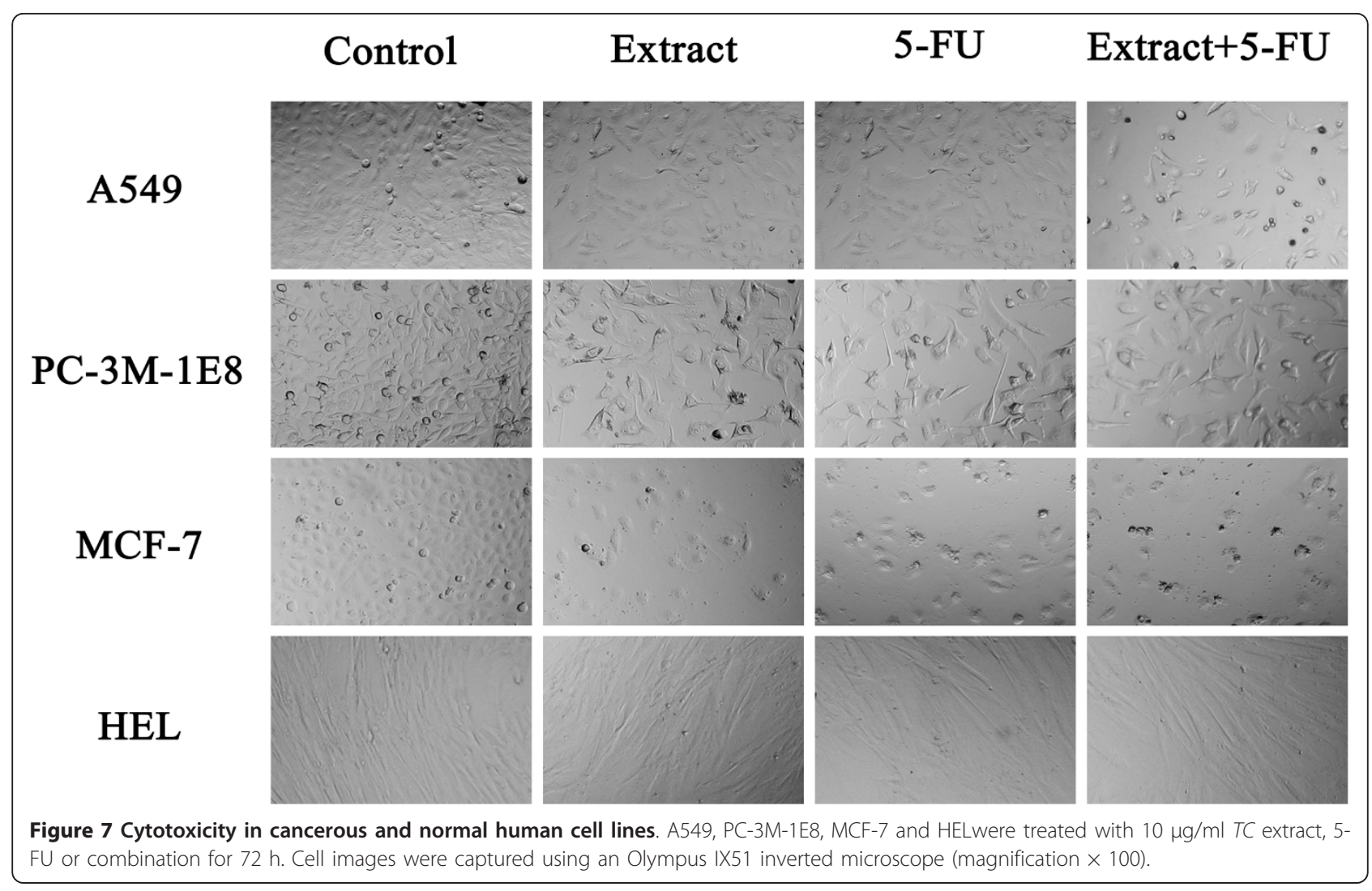

to our results, which demonstrated that the cocktail of $T C$ and 5-FU had a synergistic anticancer effect in A549, MCF-7, and PC-3M-1E8 cells. One possible explanation for this discrepancy is different exposure times: in the experiment conducted by Kano et al., the cell lines were exposed to paclitaxel and 5-FU for $24 \mathrm{~h}$,

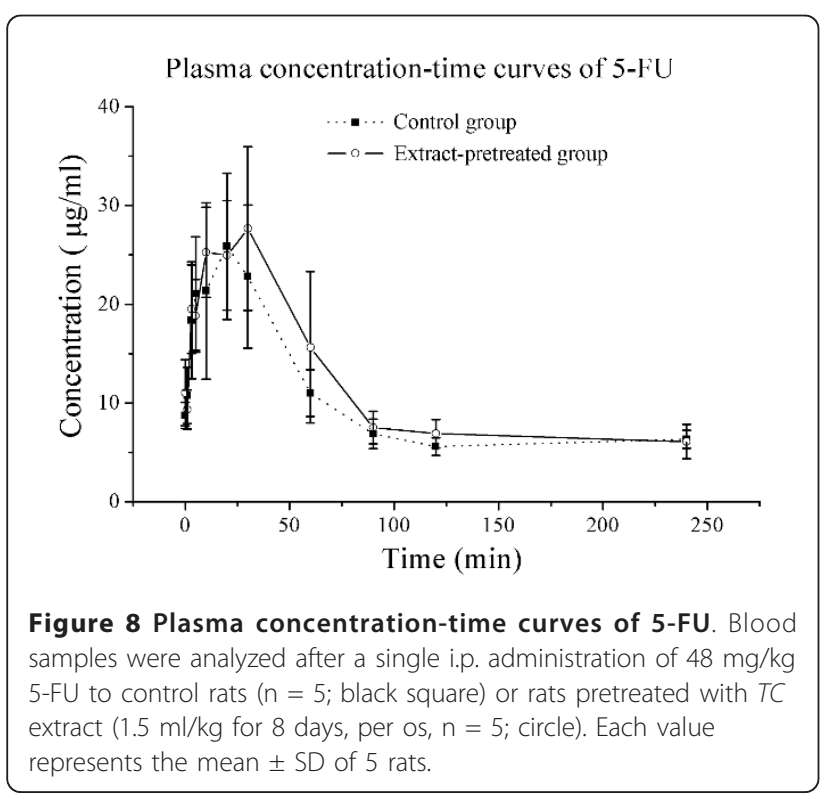

while we treated for $72 \mathrm{~h}$. The prolonged simultaneous administration of paclitaxel and 5-FU may restrain the antagonistic interaction [35]. The difference may also be due to the other taxoids besides paclitaxel found in $T C$ extract. It has been reported that simultaneous treatment with docetaxel (an analog of paclitaxel) and 5-FU resulted in synergistic tumor inhibition in colon carcinoma xenografts in mice [36].

Interaction of herbals with drugs may also bring about changes in the pharmacodynamic and pharmacokinetic properties. Pharmacodynamic interactions may occur when a conventional drug has either synergistic or

Table 2 Pharmacokinetic parameters of $5-\mathrm{FU}(48 \mathrm{mg} / \mathrm{kg}$ ) after a single i.p. injection to control rats $(n=5)$ or rats pretreated with TC extract $(n=5)$.

\begin{tabular}{lll}
\hline Parameter & Control group & Extract-pretreated group \\
\hline $\mathrm{AUC}(\mu \mathrm{g} / \mathrm{ml}) \times \min$ & $2317.81 \pm 370.12$ & $2864.17 \pm 757.25$ \\
$\mathrm{~T}_{\max }(\mathrm{min})$ & $12.53 \pm 4.88$ & $16.23 \pm 3.79$ \\
$\mathrm{C}_{\max }(\mu \mathrm{g} / \mathrm{ml})$ & $24.84 \pm 7.45$ & $23.32 \pm 4.95$ \\
$\mathrm{~V} / \mathrm{F}(\mathrm{mg} / \mathrm{kg}) /(\mu \mathrm{g} / \mathrm{ml})$ & $1.77 \pm 0.63$ & $1.83 \pm 0.41$ \\
$\mathrm{~T}_{1 / 2}\left(\mathrm{k}_{\mathrm{e}}\right)(\mathrm{min})$ & $58.5 \pm 19.67$ & $72.6 \pm 8.93$ \\
$\mathrm{~T}_{1 / 2}\left(\mathrm{k}_{\mathrm{a}}\right)(\mathrm{min})$ & $3.05 \pm 1.82$ & $3.62 \pm 1.14$ \\
\hline
\end{tabular}

AUC: area under the curve; $T_{\max }$ : time to reach the maximum concentration; $\mathrm{C}_{\max }$ : maximum concentration; $\mathrm{V} / \mathrm{F}$ : apparent volume of distribution; $\mathrm{T}_{1 / 2}\left(\mathrm{k}_{\mathrm{e}}\right)$ : elimination half-life; $T_{1 / 2}\left(k_{a}\right)$ : absorption half-life. Values are means $\pm S D$ of 5 animals. There was no significant difference between the two groups. 
antagonist activity in relation to constituents of herbal products. Pharmacokinetic interactions are due to alteration of absorption, distribution, metabolism, or elimination of a conventional drug by an herbal product. The interaction may also increase/decrease the desired pharmacological effects of the drug [37,38]. For example, in the clinical trials, the effectiveness of haloperidol was enhanced when combined with Ginkgo biloba because of its antioxidant effects [37]. While some herbal products such as garlic and St John's Wort would decrease the effectiveness of a variety of prescription medications used to treat some cancers, AIDS, heart disease and organtransplant patients [38].

The side effects of anticancer agents are a serious problem in cancer chemotherapy and an effective anticancer approach with potent activity and minimal side effects is highly desirable [15]. It is well known that some of the side effects of 5 -FU are gastrointestinal such as nausea, vomiting, and myelosuppression. The association between toxicity and high 5-FU plasma levels has been reported since the late 1970s [39-41]. Studies have shown that marked elevation and prolongation of 5-FU levels in the plasma would increase toxicity of 5-FU [29,40,41]. Pharmacokinetic data can be used to predict the likelihood of an interaction between the $T C$ extract and 5-FU. Our results indicated that $T C$ extract did not affect the pharmacokinetics of 5-FU in rats. Furthermore, at the cellular level, the cocktail had lower cytotoxicity in normal cells despite a synergistic anticancer effect. Therefore, as a cocktail, combination of 5-FU with $T C$ extract may show a possibility for enhancing the efficacy. Still, the exact mechanisms of the effects need to be further researched in our study, such as drug-metabolizing enzymes and drug transporter systems involved.

Lung cancer is the most common cause of cancerrelated death in men and women worldwide. Breast cancer is the most prevalent cancer among women and affects approximately one million women. Prostate cancer is one of the most prevalent types of cancer in men. To expand future possiblity of the cocktail used in clinic, we chose these common and prevalent cancer cell lines for the study of combined treatment. And we found that the cytotoxic effect of the combined $T C$ extract with 5-FU was strongly synergistic in the three cancer cell lines (lung cancer - A549, breast cancerMCF-7, and prostate cancer - PC-3M-1E8). Other advantages of $T C$ extract are that $T C$ needles and twigs can be obtained from artificial cuttage, making the extract constantly available, easy to prepare and inexpensive. In contrast, the extremely small quantity of paclitaxel in $T C$ [31,42] makes purified paclitaxel rather expensive, which limits its use, particularly in developing countries.

\section{Conclusions}

In this study, we reported broad-spectrum anticancer activity of the extract of $T C$ needles and twigs produced by artificial cuttage. This is the first study to explore a cocktail of $T C$ extract and 5-FU, which had synergistic effects on human cancer cells and low cytotoxicity in normal cells. These results provided important information for clinical cancer therapy. Additional, preclinical and clinical development is certainly needed to explore the uses of the $T C$ extract-5-FU cocktail for cancer therapy, and the exact mechanism of the synergistic effect should be further investigated.

\section{Additional material}

Additional file 1: Supplementary figure S1. Chemical structures of the 8 main peaks. Peaks: 1, taxine A (5.00\%); 2, 10-DAB III (1.45\%); 3, 9hydroxyl-13-acetylbaccatin III (9.38\%); 4, 7-xyl-10-DAT (9.63\%); 5, baccatin III (8.32\%); 6, 10-DAT (6.31\%); 7, cephalomannine (2.67\%); 8, paclitaxel $(2.25 \%)$.

\section{Abbreviations}

5-FU: 5-fluorouracil; AUC: area under the curve; $\mathrm{Cl}$ : combination index; $\mathrm{C}_{\max }$ : maximum concentration; fa: fraction affected; $\mathrm{PI}$ : propidium iodide; $\mathrm{T}_{1 / 2}\left(\mathrm{k}_{\mathrm{a}}\right)$ : absorption half-life; $T_{1 / 2}\left(k_{e}\right)$ : elimination half-life; $T_{\text {max }}$ : time to reach the maximum concentration; V/F: apparent volume of distribution.

\section{Acknowledgements}

This work was funded by grants provided by the National Key Technology R\&D Program (2008BAI49B04), the China National Science Foundation (81173139), and the Hongdoushan Research Foundation. We are grateful to Mr. Yongyan Wang and Mr. Jianqiang Zou for program suggestions. We also thank Mr. Zhiguo Wang for generously providing the samples of extract of TC needles and twigs produced by artificial cuttage.

\section{Author details}

${ }^{1}$ Key Laboratory of Radiopharmaceuticals, Ministry of Education, College of Chemistry, Beijing Normal University, Beijing 100875, China. ${ }^{2}$ Leonard P. Zakim Center, Dana-Farber Cancer Institute, Harvard Medical School, Boston, MA 02115, USA.

\section{Authors' contributions}

WHS carried out synergistic effect experiments, required added experiment and drafted the original manuscript. JPQ designed and carried out the pharmacokinetic experiments and drafted the original manuscript. CXG carried out the pharmacokinetic experiments and helped draft the original manuscript. WY carried out extract identification experiments. JLD performed the statistical analysis. WW carried out anticancer activities experiments. MLZ carried out the pharmacokinetic experiments. WDL made substantial contributions to conception. MH designed the study, performed mechanistic experiments and coordination and finalized the manuscript. All authors read and approved the final manuscript.

\section{Competing interests}

The authors declare that they have no competing interests.

Received: 27 June 2011 Accepted: 2 December 2011

Published: 2 December 2011

\section{References}

1. Gediya LK, Njar VCO: Promise and challenges in drug discovery and development of hybrid anticancer drugs. Expert Opin Drug Dis 2009, 4(11):1099-1111. 
2. Chia JS, Du JL, Hsu WB, Sun A, Chiang CP, Wang WB: Inhibition of metastasis, angiogenesis, and tumor growth by Chinese herbal cocktail Tien-Hsien Liquid. BMC Cancer 2010, 10:175.

3. Sandler A, Gray R, Perry MC, Brahmer J, Schiller JH, Dowlati A, Lilenbaum R, Johnson DH: Paclitaxel-carboplatin alone or with bevacizumab for nonsmall-cell lung cancer. N Engl J Med 2006, 355(24):2542-2550.

4. Chiu GNC, Wong MY, Ling LU, Shaikh IM, Tan KB, Chaudhury A, Tan BJ: Lipid-based nanoparticulate systems for the delivery of anti-cancer drug cocktails: implications on pharmacokinetics and drug toxicities. Curr Drug Metab 2009, 10(8):861-874.

5. Koppikar SJ, Choudhari AS, Suryavanshi SA, Kumari S, Chattopadhyay S, Ghanekar RK: Aqueous Cinnamon Extract (ACE-c) from the bark of Cinnamomum cassia causes apoptosis in human cervical cancer cell line (SiHa) through loss of mitochondrial membrane potential. BMC Cancer 2010, 10:210.

6. Webb MS, Johnstone S, Morris TJ, Kennedy A, Gallagher R, Harasym N, Harasym T, Shew CR, Tardi P, Dragowska WH, et al: In vitro and in vivo characterization of a combination chemotherapy formulation consisting of vinorelbine and phosphatidylserine. Eur J Pharm Biopharm 2007, 65(3):289-299.

7. Mijatovic SA, Timotijevic GS, Miljkovic DM, Radovic JM, MaksimovicIvanic DD, Dekanski DP, Stosic-Grujicic SD: Multiple antimelanoma potential of dry olive leaf extract. Int J Cancer 2011, 128(8):1955-1965.

8. Wagner $\mathrm{H}$ : Natural products chemistry and phytomedicine in the 21 (st) century: new developments and challenges. Pure App/ Chem 2005, 77(1):1-6.

9. Lei $X Y$, Kong L, Su XY, Guo M, Zou HF: Biological fingerprinting analysis of interaction between taxoids in Taxus and microtubule protein by microdialysis coupled, with high-performance liquid chromatography/ mass spectrometry for screening antimicrotubule agents. Chem Res Chinese U 2008, 24(4):411-419.

10. Hsiao WLW, Liu LA: The role of traditional Chinese herbal medicines in cancer therapy - from TCM theory to mechanistic insights. Planta Med 2010, 76(11):1118-1131

11. Yen Y, So S, Rose M, Saif MW, Chu E, Liu SH, Foo A, Jiang ZL, Su T, Cheng YC: Phase I/II study of PHY906/capecitabine in advanced hepatocellular carcinoma. Anticancer Res 2009, 29(10):4083-4092.

12. Qi FH, Li AY, Inagaki Y, Gao JJ, Li JJ, Kokudo N, Li XK, Tang W: Chinese herbal medicines as adjuvant treatment during chemo- or radio-therapy for cancer. Biosci Trends 2010, 4(6):297-307.

13. Wagner $\mathrm{H}$ : Synergy research: approaching a new generation of phytopharmaceuticals. Fitoterapia 2011, 82(1):34-37.

14. Kobayashi J, Shigemori H: Bioactive taxoids from the Japanese Yew Taxus cuspidata. Med Res Rev 2002, 22(3):305-328.

15. Wang LY, Bai LM, Tokunaga D, Watanabe Y, Hasegawa T, Sakai J, Tang WX, Bai $\mathrm{YH}$, Hirose $\mathrm{K}$, Yamori T, et al: The polar neutral and basic taxoids isolated from needles and twigs of Taxus cuspidata and their biological activity. J Wood Sci 2008, 54(5):390-401

16. Tachibana S, Ishikawa H, Itoh K: Antifungal activities of compounds isolated from the leaves of Taxus cuspidata var. nana against plant pathogenic fungi. J Wood Sci 2005, 51(2):181-184

17. Liang M, Liu WH, Zhang XC, Wang XJ, Yuan CS: The anticancer study of DaKeSu (tablet). Chinese Tradit Pat Med 1998, 20(9):43, (In Chinese).

18. Yan XM, Yan XF: The efficacy observation of DaKeSu used in clinical. Shandong Med Ind 2001, 20(4):52-53, (In Chinese).

19. Longley DB, Harkin DP, Johnston PG: 5-Fluorouracil: mechanisms of action and clinical strategies. Nat Rev Cancer 2003, 3(5):330-338.

20. Malet-Martino M, Martino R: Clinical studies of three oral prodrugs of 5fluorouracil (capecitabine, UFT, S-1): a review. Oncologist 2002, 7(4):288-323.

21. Rich TA, Shepard RC, Mosley ST: Four decades of continuing innovation with fluorouracil: current and future approaches to fluorouracil chemoradiation therapy. J Clin Oncol 2004, 22(11):2214-2232.

22. Murad AM, Petroianu A, Guimaraes RC, Aragao BC, Cabral LOM, ScalabriniNeto AO: Phase II trial of the combination of paclitaxel and 5-fluorouracil in the treatment of advanced gastric cancer - a novel, safe, and effective regimen. Am J Clin Oncol-Canc 1999, 22(6):580-586.

23. Kim YH, Shin SW, Kim BS, Kim JH, Kim JG, Mok YJ, Kim CS, Rhyu HS, Hyun JH, Kim JS: Paclitaxel, 5-fluorouracil, and cisplatin combination chemotherapy for the treatment of advanced gastric carcinoma. Cancer 1999, 85(2):295-301.

24. Haddad R, Colevas AD, Tishler R, Busse P, Goguen L, Sullivan C, Norris CM, Lake-Willcutt B, Case MA, Costello R, Posner M: Docetaxel, cisplatin, and 5- fluorouracil-based induction chemotherapy in patients with locally advanced squamous cell carcinoma of the head and neck. Cancer 2003, 97(2):412-418.

25. Zhao L, Chen Z, Wang J, Yang L, Zhao Q, Wang J, Qi Q, Mu R, You QD, Guo QL: Synergistic effect of 5-fluorouracil and the flavanoid oroxylin A on HepG2 human hepatocellular carcinoma and on $\mathrm{H}_{22}$ transplanted mice. Cancer Chemother Pharmacol 2010, 65:481-489.

26. Zeng $F$, Liu XG, Li YC, Chen G, Wang YK, Zhou SQ, Zhu WY, Huang YY, Zhou JH, Li SB, Zhang YK: Chan-Yu-Bao-Yuan-Tang and 5-fluorouracil synergistically induce apoptosis by means of the caspase-3 signaling pathway in lung and cervical cancer cells. Mol Med Rep 2011, 4(1):113-120.

27. Han M, Li JF, Tan Q, Sun YY, Wang YY: Limitations of the use of MTT assay for screening in drug discovery. J Chin Pharmaceu Sci 2010, 19:195-200.

28. Sun $Y$, Wang $W$, Sun $Y Y$, Han M: Synthesis and biological evaluation of a novel human stem/progenitor cells proliferation activator: (5-mercapto1,3,4-oxadiazol-2-yl)phenyl thiosemicarbazide (Stemazole). Eur J Med Chem 2011, 46:2930-2936.

29. Qiao JP, Gu CX, Shang WH, Du JL, Yin W, Zhu ML, Wang W, Han M, Lu WD: Effect of green tea on pharmacokinetics of 5-fluorouracil in rats and pharmacodynamics in human cell lines in vitro. Food Chem Toxicol 2011, 49:1410-1415.

30. Chou TC, Talalay P: Quantitative analysis of dose-effect relationships: the combined effects of multiple drugs or enzyme inhibitors. Adv Enzyme Regul 1984, 22:27-55

31. Fu YJ, Sun R, Zu YG, Li SM, Liu W, Efferth T, Gu CB, Zhang L, Luo H: Simultaneous determination of main taxoids in Taxus needles extracts by solid-phase extraction-high-performance liquid chromatography with pentafluorophenyl column. Biomed Chromatogr 2009, 23(1):63-70.

32. Jenniskens LHD, vanRozendaal ELM, vanBeek TA, Wiegerinck PHG, Scheeren HW: Identification of six taxine alkaloids from Taxus baccata needles. J Nat Prod 1996, 59(2):117-123.

33. Zu YG, Fu YJ, Li SM, Sun R, Li QY, Schwarz G: Rapid separation of four main taxoids in Taxus species by a combined LLP-SPE-HPLC (PAD) procedure. J Sep Sci 2006, 29(9):1237-1244.

34. Wang YF, Yu SH, Dong M, Zhang ML, Huo CH, Shi QW: Chemical studies on Taxus cuspidata. Chem Biodivers 2010, 7(7):1698-1716.

35. Kano Y, Akutsu M, Tsunoda S, Ando J, Matsui J, Suzuki K, Ikeda T, Inoue Y, Adachi Kl: Schedule-dependent interaction between paclitaxel and 5fluorouracil in human carcinoma cell lines in vitro. Br J Cancer 1996, 74(5):704-710

36. Wada Y, Yoshida K, Suzuki T, Mizuiri H, Konishi K, Konishi K, Ukon K, Tanabe K, Sakata Y, Fukushima M: Synergistic effects of docetaxel and S-1 by modulating the expression of metabolic enzymes of 5-fluorouracil in human gastric cancer cell lines. Int J Cancer 2006, 119(4):783-791.

37. Chavez ML, Jordan MA, Chave PI: Evidence-based drug-herbal interactions. Life Sci 2006, 78:2146-2157.

38. Rapaka RS, Coates PM: Dietary supplements and related products: a brief summary. Life Sci 2006, 78:2026-2032.

39. Saif MW, Choma A, Salamone SJ, Chu E: Pharmacokinetically guided dose adjustment of 5-fluorouracil: a rational approach to improving therapeutic outcomes. J Natl Cancer Inst 2009, 101:1543-1552.

40. Hillcoat BL, McCulloch PB, Fiqueredo AT, Ehsan MH, Rosenfeld JM: Clinical response and plasma-levels of 5-fluorouracil in patients with colonic cancer treated by drug infusion. Br J Cancer 1978, 38:719-724.

41. Vogel S, Presant C, Ratkin G, Klarhr C: Phase I study of infusion 5fluorouracil (5FU) plus thymidine (T). Proc Am Assoc Cancer Res 1978, 19:232.

42. Jennewein S, Croteau R: Taxol: biosynthesis, molecular genetics, and biotechnological applications. Appl Microbiol Biotechnol 2001, 57:13-19.

\section{Pre-publication history}

The pre-publication history for this paper can be accessed here: http://www.biomedcentral.com/1472-6882/11/123/prepub

\section{doi:10.1186/1472-6882-11-123}

Cite this article as: Shang et al: Anticancer activity of an extract from needles and twigs of Taxus cuspidata and its synergistic effect as a cocktail with 5-fluorouracil. BMC Complementary and Alternative Medicine 2011 11:123. 